\title{
Expanding Learning Presence to Account for the Direction of Regulative Intent: Self-, Co- and Shared Regulation in Online Learning
}

\author{
Suzanne Hayes \\ Empire State College, State University of New York \\ Sedef Uzuner Smith \\ Lamar University \\ Peter Shea \\ University at Albany, State University of New York
}

\begin{abstract}
As the pivotal role of self-regulation has been widely accepted in online learning literature, much interest is focused on identifying pedagogical strategies to help foster regulatory behaviors in online learners. The authors of this article argue that the learning presence (LP) construct, a recently proposed addition to the Community of Inquiry (CoI) theoretical framework of online learning, needs to be included in these conversations. To this end, they re-articulate and clarify the underlying structure of LP by drawing on the theoretical models of self-regulation, co-regulation, and socially shared regulation. They further present examples to illustrate how LP can manifest itself in learners' discourse in the online learning environment. Finally, they conclude by outlining strategies online instructors can use to help learners execute regulatory behaviors and thus demonstrate LP in online courses.
\end{abstract}




\section{Introduction}

There is a growing body of literature that employs the Community of Inquiry (CoI) frameworkdeveloped by Garrison, Anderson, and Archer (2000) - to investigate and explain the effectiveness of online teaching and learning (see Arbaugh, 2008; Benbunan-Fich \& Hiltz, 2003; Boston et al. 2009; DiRienzo \& Gregory, 2014; Kang \& Im, 2013; Stodel, Thompson, MacDonald, 2006). This framework asserts that successful online learning occurs through the cultivation of three forms of presence: social presence, teaching presence, and cognitive presence. Social presence refers to behaviors that enhance rapport, trust, and collegiality among online course participants; teaching presence refers to the design and facilitation of learning tasks and their assessment; and cognitive presence refers to shared negotiation of meaning through knowledge construction. As Swan and Ice (2010) stated, "Since its formulation, the CoI framework has been adopted and adapted by educators worldwide. It has been used in a variety of ways to inform both research and practice in online and blended learning” (p. 1).

Recently, we highlighted the CoI framework's lack of attention to the attitudes and behaviors that engaged and active students bring to their individual and collaborative online activities (Shea et al., 2012, 2013, 2014). Specifically, we described prior research efforts to examine evidence of teaching, social, and cognitive presence within all areas of an online course which resulted in examples of learner discourse that could not be reliably coded as the three key CoI indicators (Shea, Hayes \& Vickers, 2010). Further investigation suggested to us that learners' discourse focusing on individual and group efforts to regulate their learning (such as understanding instructions provided by the instructor, dividing up tasks, managing time and setting group project goals, etc.) could not be accounted for by the existing constructs found within the CoI framework. To account for these missing behaviors, we called for inclusion of a new presence into the framework, called learning presence (LP). We defined LP "by the phases of forethought, performance, and reflection associated with self-regulated learning, but with emphasis on the goals and activities of online learners specifically" (p. 10). We further proposed that the LP construct is "simultaneously self- and co-regulatory in nature as it is predicated on not only individual efforts, but also group dynamics within collaborative learning activities” (p. 10).

Given that exploration and discussion of the LP construct is in its early stages (see e.g., Akyol \& Garrison, 2011; Garrison \& Akyol, 2013; Hayes, 2014; Mayordomo \& Onrubia (In press); Traver, Colchok, Bidjerano \& Shea, 2014; Wertz, 2014), we propose further clarification of its underlying structure is needed. In our earlier studies described above we suggested the LP construct was "simultaneously self- and co-regulatory in nature." This statement, while accurate, requires further elaboration. In this paper, we will explicate and exemplify the self- and co-regulatory processes the LP construct encompasses by drawing on salient differences among self-regulation, co-regulation, and socially shared regulation identified by Volet, Vauras, and Salonen (2009), Hadwin, Järvelä, and Miller (2011), Hadwin and Oshige (2011), and Grau and Whitebread (2012).

\section{Learning Presence Construct Viewed through Self-Regulation, Co-Regulation, and Shared Regulation}

The notion of self-regulation in education literature is generally based on Zimmerman's (1989, 1990, 2008) three-phase model of the cyclical processes of planning (forethought), performance (monitoring and strategy use), and evaluation (reflection). In this model, self-regulation is described as "proactive processes that students use to acquire academic skill, such as setting goals, selecting and deploying strategies, and self-monitoring one’s effectiveness" (Zimmerman, 2008, p. 166). The self-prefix in self-regulation indicates the learner is concerned with regulating his/her own thinking, motivation and behavior during learning. Against this theoretical backdrop, Grau and Whitebread (2012) refer to selfregulation as "intra-personal regulation” (p. 401). Additionally, the emphasis on the word 'proactive' in 
Zimmerman's formulation indicates self-regulation is a product of deliberate action. This idea is reinforced in Hadwin, Järvelä, and Miller's (2011) definition of self-regulation when they wrote, "Selfregulation of learning refers to a learner's deliberate planning, monitoring, and regulating of cognitive, behavioral, and motivational/emotional processes towards completion of an academic task/goal” (p. 68).

In our work, Zimmerman's (1989, 1990, 2008) three-phase model of the cyclical processes of planning (forethought), performance (monitoring and strategy use), and evaluation (reflection) also formed the theoretical background for the LP construct to represent the regulatory activities of online learners. However, in our description of the LP construct, we conflated the intrapersonal (regulating self) and interpersonal (regulating others) dimensions rather than separating them. As Iiskala, Vauras, Lehtinen, and Salonen (2011) wrote, intrapersonal regulation is not equivalent to interpersonal regulation, and vice versa, therefore, both types of regulation "should be conceptualized differently" (p. 379). In line with this reasoning, we define the self-regulation aspect of LP as "Regulation behavior used by the [learner] mainly to regulate himself/herself, with no apparent intentions to influence other [learners'] cognitions, emotions and behaviors" (Grau \& Whitebread, 2012, p. 411). Next, we also delineate the interpersonal (social) aspects of LP.

In the literature on student regulation of learning, the interpersonal dimension of regulation is referred to as co-regulation (Salonen, Vauras, \& Efklides, 2005; Volet, Summers, \& Thurman, 2009). Coregulation means regulation directed toward a specific member of a group in a collective activity, and it stands in contrast to self-regulation where regulation is directed toward one's own individual performance. To convey the meaning of co-regulation, Grau and Whitebread (2012) use the following examples:

- $\quad$ Peer tutoring in which one [learner] monitors or controls another [learner] who might need some help with some aspects of the task

- When a [learner] is trying to influence another [learner's] behavior either because the second is not doing well in the task or is not behaving properly in order to carry out the activity.

To expand Grau and Whitebread’s definition a bit farther, we can apply Hadwin, Järvelä, and Miller's (2011) idea that co-regulation is "a manifestation of emergent interaction within [Vygotksy's] . . . zone of proximal development” (p. 73). It is this expanded notion of co-regulation that we draw on here to explicate the co-regulatory dimension of the LP construct. As such, the co-regulatory aspect of LP refers to asymmetrical situations whereby one member of a group with more knowledge and skills provides scaffolding support for another.

Shared regulation is another term used in the literature to account for the social aspects in the regulation of learning (Iiskala, Vauras, \& Lehtinen, 2004; Vauras, Iiskala, Kajamies, Kinnunen, \& Lehtinen, 2003). Unlike co-regulation, which includes asymmetrical scaffolding, shared regulation refers to "a symmetrical style of communication" wherein regulation is directed toward "some shared understanding or strategic decision within the group" (Grau \& Whitebread, 2012, p.5). According to Volet, Vauras, and Salonen (2009), shared regulation "is considered the most profoundly social mode of regulation, because it refers to individuals' metacognitive processes that operate as a genuine social entity, aimed at a single direction, that is, the fully shared goal for the activity” (p. 219). Put another way, Hadwin and Oshige (2011) state shared regulation refers to those "processes by which multiple others regulate their collective activity." This collective regulation reflects "shared awareness of goals, progress, and tasks toward co-constructed regulatory processes” (p. 254-255). In light of these descriptions, we argue the interpersonal dimension of regulation encompassed by the LP construct is shared regulation, which refers to symmetrical situations where members of a group collectively set goals, track their progress, use strategies, and consider their effectiveness in the service of a shared outcome. 
In sum, the above-mentioned differences among self-regulation, co-regulation, and shared regulation have led us to conclude that the LP construct includes the three-phase model of the cyclical processes (planning, monitoring, and reflection) at three levels: an individual looking after his/her own activity (self-regulation); an individual scaffolding and regulating another's learning (co-regulation); and individuals working together to regulate each other's learning (shared regulation). Below we will demonstrate each regulation type within the LP construct with examples found in the discourse of online learners. The examples will show how LP can manifest itself in learners' discourse in the online learning environment.

\section{Examples of LP Showing Direction of Intentionality: Self-, Co-, and Shared Regulation}

Before we illustrate the three dimensions of the LP construct with examples, we must describe the context from which we selected those examples as well as the methodology we used for their identification and analysis.

\section{Context}

The course, Advanced Health Assessment, which was offered in a school of nursing at a college in the northeast, provided the setting. It was delivered via Moodlerooms during the 2013 fall term. Eighteen students were enrolled in the course. Before the class was divided into four teams for a sixweek-long collaborative project, we obtained consent from nine of the students (constituting two teams) to access, read, analyze and use anonymized quotes from their project related conversations. The project required teams to develop a plan of care for an assigned case, using a wiki as their authoring tool for the final product. Both teams were provided with identical project instructions. They were also provided identical workspaces within the Moodlerooms to support their planning and decision-making. These workspaces were a discussion area for asynchronous communications and an optional chat area for real time conversations. The LP examples we provide here come from these discussions and chats.

\section{Methodology}

We began our search for examples for this article by creating a chronological transcript of the two teams' discussions and chats, and by replacing all names with pseudonyms. The transcripts yielded a total of 435 messages. To ensure systematic selection of examples from these messages, we decided to first count frequencies of LP in them and then qualitatively examine the regulative direction in segments of those messages.

For our first task, we employed quantitative content analysis, which is often used in studies of computer-mediated communications and learning (e.g., DeWever, Schellens, Valcke, \& Vankeer, 2006; Gunawardena, Lowe \& Anderson, 1997; Henri, 1992; Rourke, Anderson, Garrison \& Archer, 2001) to create categorizations and frequency counts based on a pre-established or emergent coding scheme. Using the LP coding scheme (Shea et al. 2012; Shea et al., 2013; Shea et al., 2014) with some modifications (see Appendix), we identified occurrences of LP in both teams' transcripts. To calibrate consistency in applying the LP codes, two of us first practiced coding using two archived team discussions from an earlier term of the same course (we call this phase 'practice coding'). Because the LP construct addresses the regulatory processes students display, instructor postings were excluded from our analysis. After calibration, we shifted our attention to the discussion and chat postings generated by the nine students who comprised the two teams identified above (we call this phase 'actual coding'). During the practice coding and the actual coding, we first worked independently to examine each sentence in every posting to identify one of the four LP categories (forethought and planning, monitoring, strategy use, and reflection). 
Following this, we met to negotiate our disagreements. We used Holsti's coefficient of reliability to calculate inter-rater reliability (IRR). Neuendorf (2002) considers an IRR of .70 to be reliable. In both the practice and actual coding, we obtained an IRR that exceeded .70 initially and reached $100 \%$ agreement during negotiation of disagreements (see Table 1).

Table 1 Inter-rater Reliability for LP Coding: Holsti’s Coefficient of Reliability

\begin{tabular}{lll}
\hline & $\begin{array}{l}\text { Initial } \\
(\mathrm{CR})\end{array}$ & $\begin{array}{l}\text { Negotiated } \\
(\mathrm{CR})\end{array}$ \\
\hline Practice Coding 1 & 0.81 & 1.00 \\
Practice Coding 2 & 0.88 & 1.00 \\
Actual Coding Transcript 1 & 0.77 & 1.00 \\
Actual Coding Transcript 2 & 0.79 & 1.00 \\
\hline
\end{tabular}

The aggregated findings for the two teams yielded a total of 396 LP indicators which were distributed as follows:

Table 2 Frequency of LP Indicators

\begin{tabular}{llllllllll}
\hline \multicolumn{2}{l}{$\begin{array}{l}\text { Forethought } \\
\text { Planning }\end{array}$} & $\&$ & \multicolumn{2}{l}{ Monitoring } & \multicolumn{2}{l}{ Strategy Use } & \multicolumn{2}{l}{ Reflection } & \multicolumn{2}{l}{ Total } \\
\hline Count & $\%$ & Count & $\%$ & Count & $\%$ & Count & $\%$ & Count & $\%$ \\
\hline 116 & 29.2 & 183 & 46.2 & 90 & 22.7 & 4 & 1.9 & 393 & 100 \\
\hline
\end{tabular}

For our second task of qualitatively examining the regulative direction in segments that were identified as LP in the transcripts, we employed directed qualitative content analysis. This is a structured approach where textual content is coded into categories based on an existing theoretical framework or theory (Hsieh \& Shannon, 2005). During this analysis, we applied the three categories of regulation listed below, which were derived from our preceding review, to the LP coded messages.

- Self-regulation when the utterances included "behavior used by the [learner] mainly to regulate himself/herself, with no apparent intentions to influence other [learners'] cognitions, emotions and behaviors” (Grau \& Whitebread, 2012, p. 411).

- Co-regulation when the utterances included asymmetrical situations whereby one member of a group who has more knowledge and skills provides scaffolding support for another

- Shared regulation when the utterances included symmetrical situations where members of a group collectively set goals, track their progress, use strategies, and consider their effectiveness in the service of a shared outcome.

So far, we have described the systematic efforts we made to select the examples to show how LP can manifest itself in learners' discourse in the online learning environment. Below, we present the examples.

\section{Self-Regulation Dimension of LP}

In our discussion above, we argued the LP construct encompasses students' regulatory activities at three levels, one of which is self-regulation, referring to an individual looking after his/her own activity. In the transcripts we observed numerous instances in which students verbalized their selfregulation processes. For example, in Figure 1, a student, Crystal, identifies a problem (lines 1-2), which is uploading a file to the team's wiki, and then acts to resolve this problem on her own (lines 4-5) by contacting the help desk. Crystal's use and verbalization of self-monitoring and help seeking strategies are examples of the self-regulatory aspect of the LP construct: She identifies a problem and takes 
intentional productive action to advance her performance. It is this sense of student-initiated intentional productive action in online learning that the LP construct accounts for with its self-regulation component.

\begin{tabular}{llll}
\hline Line & Student Posting & LP Code & \\
\hline 1 & Crystal: I just want you all to know that I am having a problem & MO2 & Identifying problem \\
2 & with the wiki site. When I click on the files tab, I do not have & & \\
3 & the icon on the bottom that says "Edit wiki files.” Therefore I & & Seeking, offering or \\
4 & cannot add a file. I was on the phone today with tech support & SU1 & providing guidance \\
5 & and they were unable to resolve my problem. They will notify & & \\
6 & me by email as soon as it is corrected. & & \\
7 & & & \\
\hline
\end{tabular}

Figure 1. Excerpt from asynchronous discussion illustrating self-regulation.

In the next example (see Figure 2) the first student, Sarah, raises a series of questions related to how and where the team should present their individual contributions for their care plan. Rather than answering these questions directly, a second student, Fern, demonstrates metacognitive awareness and surfaces her own concerns about the work she has just recently completed. In doing so, Fern describes a series of selfinitiated acts of self-regulation: her awareness of her own learning behaviors in terms of recognizing her strengths and weaknesses (lines 8-9); her recognition of the need for better formatting as an area for improvement (lines 11-12); and asking for assistance to accomplish this (lines 13-15). It is notable that Fern not only identified these specific concerns independently, but that she was also able to verbalize them to her peer, Sarah. Again, as is the case in the previous excerpt, Fern's verbalization of her selfregulatory activities points to the conscious deliberate actions she has undertaken to assume responsibility for her learning. This awareness of personal conditions (e.g., cognitive states, abilities, and actions) and seeking ways to improve those conditions is a critical component of the self-regulation aspect of LP.

\begin{tabular}{|c|c|c|c|c|}
\hline Line & Student Postings & \multicolumn{3}{|c|}{ LP Code } \\
\hline 1 & Sarah: Hi all, I was just thinking that it might be helpful to present & & & \\
\hline 2 & the care plans and information on each of our selected CHF & & & \\
\hline 3 & (congestive heart failure) topics as it would be presented in an & & & \\
\hline 4 & educational pamphlet. When creating the final project, this would & & & \\
\hline 5 & make it easier to put all the pieces together. Also, I was wondering if & & & \\
\hline 6 & we should create the pamphlet in a Word program or use the Wiki & & & \\
\hline 7 & project place? & & & \\
\hline 8 & Fern: Hi all, Computer formats and templates are not my strong & MO6 & Recognizing & \\
\hline 9 & area. Please review the wiki for the template... & & $\begin{array}{l}\text { learning } \\
\text { behavior(s) i } \\
\text { self /others }\end{array}$ & in \\
\hline 10 & I entered by information part of the care plan with & MO4 & Evaluating & \\
\hline 11 & interventions/prevention, goals for Libby. It needs to be formatted & & quality & \\
\hline 12 & better, for easier reading for the patient. & & & \\
\hline 13 & I need help with the format to make sure that all information fits on & SU1 & Seeking, & \\
\hline 14 & the page. There is [sic] five columns, too many [and the] font [is] too & & offering & or \\
\hline 15 & small for the patient to read. Help please. & & $\begin{array}{l}\text { providing } \\
\text { guidance }\end{array}$ & \\
\hline 16 & Please advise if I left anything out or need to add more information. & & & \\
\hline 17 & Thank you for your help. & & & \\
\hline
\end{tabular}

Figure 2. Excerpt from asynchronous discussion illustrating self-regulation. 


\section{Co-Regulation Dimension of LP}

A second level of regulatory activity the LP construct encompasses is co-regulation. Coregulation is evident when one learner provides scaffolding and support to another. Displayed in the student-student exchange in Figure 3, Samantha provides scaffolding to Pat to help her accomplish the given task by shifting Pat's view of a potential problem into an unrecognized opportunity. The excerpt begins with Pat indicating she has limited access to health care professionals who would be suitable to interview for the case study. Pat identifies this potential barrier to her participation in the team's project and conveys it to her team members (lines 5-9). In response, Samantha offers guidance, a form of intentional strategy use, to help Pat realize she does in fact have access to a professional who is suited to the requirements of the case study (lines 15-17). In the process of this interaction, we see the following aspects of co-regulation that the LP construct encompasses: One student exhibits misunderstandings or gaps in knowledge that prevents him/her from successfully completing a task; and another student takes the opportunity to remediate those misunderstandings or knowledge gaps through interactions that can be characterized as “I see something that you don't see, and I can help.”

\begin{tabular}{|c|c|c|c|}
\hline Line & Student Postings & \multicolumn{2}{|l|}{ LP Code } \\
\hline 1 & Pat: Hi, I was again reading the directions tonight and I have come to & \multirow[t]{9}{*}{ MO2 } & \multirow{9}{*}{$\begin{array}{l}\text { Identifying } \\
\text { problems }\end{array}$} \\
\hline 2 & the same conclusion that we first have to do an interview with & & \\
\hline 3 & another profession. My question is: are we going to be given a new & & \\
\hline 4 & case study or are we going with the previous one "Manny"? I work & & \\
\hline 5 & in home care, so I have access to Medical Social Workers, and & & \\
\hline 6 & Registered Dietitians, the only issue I see is that most of the clientele & & \\
\hline 7 & that these professions deal with are seniors. [the project is about an & & \\
\hline 8 & overweight youth with asthma] & & \\
\hline 9 & & & \\
\hline 10 & & \multirow[t]{8}{*}{ SU1 } & \multirow{8}{*}{$\begin{array}{l}\text { Seeking, } \\
\text { offering or } \\
\text { providing } \\
\text { guidance }\end{array}$} \\
\hline 11 & detailed case study. I can interview a dietician, as she actually & & \\
\hline 12 & specializes in peds [pediatric] patients. (assuming the patient is still & & \\
\hline 13 & obese) -- I already spoke to one on my floor about the possibility of & & \\
\hline 14 & an interview. Although if he isn't obese then she won't be able to & & \\
\hline 15 & contribute much. Pat, what about interviewing a social worker? & & \\
\hline 16 & They usually deal with all types of patients and families. & & \\
\hline 17 & & & \\
\hline
\end{tabular}

Figure 3. Excerpt from synchronous chat illustrating co-regulation.

The interactions featured in the next excerpt (Figure 4) illustrate another instance where Samantha offers technical help (about wiki use) to another student, Crystal. In this series of exchanges, it is notable that Samantha offers procedural help and guidance to check or confirm Crystal's understanding (lines, 1-2, 4, 7, 11-14). Crystal, in turn, uses self-monitoring to identify where she encountered problems (line 3) and conveys her willingness to remain engaged by "trying again" (lines 9-10). Ultimately this interaction marked by Samantha's co-regulative actions served as a valuable investment of effort because Crystal was then able to work independently in the wiki for the duration of the project. 


\begin{tabular}{|c|c|c|c|c|}
\hline Line & Student Postings & LP Co & & \\
\hline $\begin{array}{l}1 \\
2\end{array}$ & $\begin{array}{l}\text { Samantha: Do you want to go to the wiki page now and we can have } \\
\text { you add something in? }\end{array}$ & SU1 & $\begin{array}{l}\text { Seeking, } \\
\text { offering } \\
\text { providing } \\
\text { guidance }\end{array}$ & or \\
\hline 3 & $\begin{array}{l}\text { Crystal: I just tried to add the [text for the] cover page and couldn't do } \\
\text { it }\end{array}$ & MO2 & $\begin{array}{l}\text { Identifying } \\
\text { problems }\end{array}$ & \\
\hline 4 & Samantha: Hmmm. Are you copying and pasting it in? & MO1 & $\begin{array}{l}\text { Checking } \\
\text { confirming }\end{array}$ & or \\
\hline $\begin{array}{l}5 \\
6\end{array}$ & $\begin{array}{l}\text { Crystal: I think Pat put the pictures of the different HCP [health care } \\
\text { providers] in the files }\end{array}$ & MO2 & $\begin{array}{l}\text { Identifying a } \\
\text { Problem }\end{array}$ & \\
\hline 7 & Samantha: You can't add the whole file separately... & SU1 & $\begin{array}{l}\text { Seeking, } \\
\text { offering } \\
\text { providing } \\
\text { guidance }\end{array}$ & or \\
\hline 8 & Samantha: I've been using copy/paste [in the wiki's editor.] & SU1 & $\begin{array}{l}\text { Seeking, } \\
\text { offering } \\
\text { providing } \\
\text { guidance }\end{array}$ & or \\
\hline $\begin{array}{l}9 \\
10\end{array}$ & $\begin{array}{l}\text { Crystal: I will try again. I did add [information that the family] add that } \\
\text { all speak and understand English. }\end{array}$ & MO5 & $\begin{array}{l}\text { Appraising } \\
\text { personal } \\
\text { engagement }\end{array}$ & \\
\hline $\begin{array}{l}11 \\
12 \\
13 \\
14\end{array}$ & $\begin{array}{l}\text { Samantha: Okay... good. We can write directly in the document... } \\
\text { Where you see the FILES tab, there is also an EDIT tab... and you can } \\
\text { highlight your Word document, copy it and then paste.... I did that with } \\
\text { mine in the different sections. }\end{array}$ & SU1 & $\begin{array}{l}\text { Seeking, } \\
\text { offering } \\
\text { providing } \\
\text { guidance }\end{array}$ & or \\
\hline
\end{tabular}

Figure 4. Excerpt from synchronous chat illustrating co-regulation.

The co-regulation aspect of LP, as evidenced in Figures 3 and 4, points to asymmetric, scaffolding-like situations constructed between two students: a student who has familiarity or better understanding of a task/concept assists another student who needs help. It is this collaborative, peer-topeer scaffolding in online learning that the LP construct accounts for with its co-regulation component.

\section{Shared Regulation Dimension of LP}

In addition to self- and co-regulation, another level of regulatory activity the LP construct encompasses is shared regulation. In the following examples, we demonstrate online students' collective regulatory intents which are directed toward accomplishing a communal goal. The first illustrates how students undertake purposeful regulative actions to realign their group's direction after receiving feedback from their instructor. In the second, the members of another team makes a series of regulative decisions as they work on a plan for completing their assignment. 
The dialogue featured in Figure 5 takes place during a scheduled team chat at the mid-point of the project. In this dialogue, the team is about to face an important decision. Earlier in the day, the instructor posted an announcement informing the team they had misconstrued the nature of the written assignment they were to complete (i.e., rather than developing a creative inter-disciplinary plan of care emphasizing health promotion, students created a research paper). In order to refocus the team's efforts to meet the instructor's expectations, one of the team members, Fern, notifies the team of the instructor's feedback by cutting and pasting the text of the instructor's announcement directly into the chat (lines 1-2). She purposely shares this information to highlight the need for the team to make an adjustment in their strategy to meet the instructor's creativity requirement (lines 6-9, 12-13). In response, the team members propose alternative suggestions, using the pronoun 'we.' The use of this pronoun indicates the team members' creation of a group perspective rather than an individual one. After exhausting possibilities, the team collectively agrees on a strategy to follow.

\begin{tabular}{lll}
\hline Line & Student Postings & LP Code \\
\hline 1 & Fern: I just copied and pasted professor's announcement [above], & SU2 Reviewing \\
2 & for us to review. &
\end{tabular}

3 Fern: professor just posted this at 12:22 P.M. today

$4 \quad$ Denise: thank you for re-posting, I haven't seen this. Now I'm a MO5

$5 \quad$ little confused as well on what we're exactly supposed to do.

Appraising

personal reaction

6 Fern: I guess this changes things a bit, So it looks like forget the APA format[ed paper], and we each need to do a care plan based on the professional we interviewed based on Libby [our assigned case study]. Thoughts??

10 Denise: are we setting up the care plan like a diagram though? Or 11 just a regular care plan?

12 Fern: The diagram was a creative way to present data for plan. We MO2 13 need to decide on creative presentation

14 Denise: any ideas on that?

15 Sarah: I'm not sure how to create a diagram

16 Molly: Just an idea but maybe an illustration of the body showing 17 symptoms

18 Denise: what if we made a concept map?

SU4

Making adjustment in strategy

MO1

Checking or confirming

Identifying problem

MO2 Identifying problem

SU1 Seeking, offering or providing guidance

SU1 Seeking, offering or providing guidance

SU1 Seeking, offering or providing guidance the plan to care for $d x$ [diagnosis], etc. Basically a care plan. Fern: Me either, maybe we can do educational handout pamphlet? 
24 Concept map sounds good too, but I do not know how to format

25 boxes to input data, It may be hard to visualize, if we do we may

26 need to do several concept maps for each professional we

27 interviewed for case study.

28 Denise: I'm okay with whatever everyone else is. I like the idea of

29 a pamphlet.

30 Molly: Yes, a pamphlet is a good idea.

31 Sarah: I agree on the pamphlet.

Figure 5. Excerpt from synchronous chat illustrating shared regulation. Note: Not all applicable LP codes are shown in this example.

The shared regulation aspect of the LP construct is also evident in Figure 6 which highlights a conversation that took place as one team worked toward establishing a shared plan for how to approach the assignment. As seen in the previous example, this team also uses inclusive pronouns such as "we" and "ours," indicating a clear direction for their regulatory intent.

Here, shared regulation commences with students using collective forethought and planning as they consider how they will coordinate their activities and assign specific tasks to each other to complete the assignment (lines 6-24). This team also uses monitoring as they acknowledge problems and check for mutual understanding (lines 33-39). Lastly, the team moves toward a better shared understanding of their assignment (lines 40-52) as a result of one team member effectively demonstrating the value of using a specific regulatory strategy: reviewing course content (i.e., instructions) when beginning an assignment.

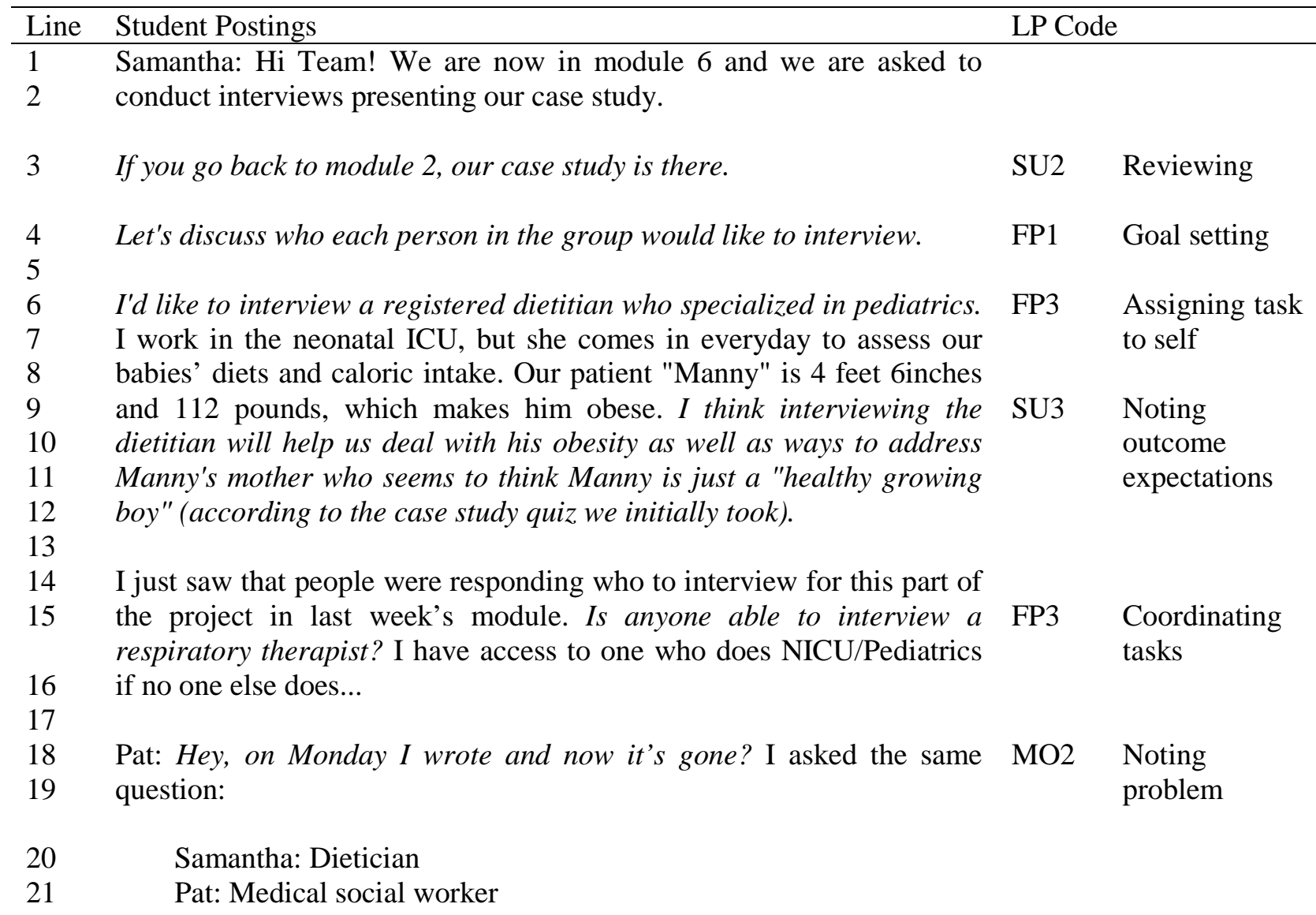


Althea: Respiratory

Crystal: Physician or NP [Nurse Practitioner]

We need to decide what the questions will be and how many? I wrote these same questions somewhere in here????

Crystal: Hi Team, I have no problem conducting interviews with both a physician and an NP. I will post questions relative to these specialties by Saturday morning.

I think if we all do this then our efforts will be coordinated and someone in the group may identify a question missed. I can conduct my actual interviews on Monday and Tuesday and will post the transcription on Wednesday. Is that OK with everyone? Pat, I cannot find your questions either.

Samantha: I wasn't under the impression that we needed to decide on questions together. If we are each doing different specialties/health care areas, then none of us would really ask the same thing anyways. It's more of a discussion than a formal interview...As if asking another health care worker for their opinion on a patient. I didn't see that we needed to come up with questions as a team, did anyone else?

The instructions I found were:

The Interview: For this project, each team member (student) will interview one individual (representing a different discipline of the health care team) to obtain input on the priorities for the assigned case study. You should have input from a variety of sources (physician, nurse practitioner, pharmacist, case manager, dietician, physical/occupational therapist, respiratory therapist, counselor, etc.). The interview should be with someone that you have convenient access to, such as a colleague at your place of employment. Present the known case study information to that individual, and ask for his/her perspective on priorities for patient care. Discuss this input with your team members, and integrate the information into the plan of care.

Figure 6. Excerpt from asynchronous discussion illustrating shared regulation. Note: Not all applicable LP codes are shown in this example.

FP3 Coordinating tasks

FP3 Assigning tasks to self or others

Noting outcome expectation

MO1 Checking or confirming

SU2 Reviewing

SU2 Reviewing Crystal: I went back and read the instructions again. I only see what
you just posted for clarification. I must have had a senior moment blush. I will go ahead then and interview both the NP and Physician. What is our target day to have this done by? 
All in all, students' interactions as displayed in Figures 5 and 6 exemplify symmetrical situations where team members direct their efforts toward shared goals, purpose, decisions and outcomes. It is this collective thinking and acting of online learners in the service of a shared outcome that the LP construct accounts for with its shared regulation component.

\section{Implications for Practice}

Some online learners may instinctively know how to plan and monitor their performance-as well as the performance of their team members-and therefore demonstrate LP at three levels (self-, co-, and shared-regulation). Others may be self-taught or self-trained, demonstrating regulatory behaviors as a result of the strategies they learned through trial and error. And still others may never have a handle on how to regulate their own or others' learning. In this section, we outline strategies online instructors can use to help all learners execute regulatory behaviors and thus demonstrate LP in online courses.

Earlier in this paper, we defined the self-regulation aspect of LP as an individual looking after his/her own activity. Drawing on the idea that self-regulation is guided by feedback (Hadwin, 2008) and building on the explanations we have provided so far, a first practical implication emanating from this paper is that online instructors should provide their students with qualitatively good, goal-directed feedback. Research shows that feedback where a learner's current performance is compared against a goal/standard serves as the trigger to initiate self-regulation (Shapiro \& Schwartz, 2000). As Nicol and Macfarlane-Dick (2006) wrote, "It is these comparisons that help the student determine whether current modes of engagement should continue as is, or if some type of change is necessary” (p. 202). Therefore, to trigger the self-regulation aspect of LP, it is important to make goals and standards explicit in course documents, such as syllabi, assessment instructions, rubrics, etc., and make specific references to these in the feedback provided. In addition to being goal-directed, feedback given to online learners should be directly-actionable. If the learners lack awareness that they must close the gap between their current and targeted performance, they may not be able to make sense of what they are expected to do. This, however, does not mean online instructors should give learners straight directions or provide correction. Rather, they should provide hints for improvement and ask questions that provide learners with an opportunity to clarify their thoughts and rethink their actions.

It is important to note feedback alone is not helpful in triggering the self-regulation aspect of LP in online students. Sometimes learners receive goal-directed and directly-actionable feedback, yet they are not able to construct a personal interpretation of that feedback and act accordingly. Similarly, for some learners, understanding or making sense of the provided feedback does not mean they will act on it; they may choose to ignore the feedback. Determining how learners make sense of the feedback they have received and whether or not they will act on it can be difficult. This is where encouraging learners to reflect on the feedback they received becomes crucial. Whenever possible, after providing feedback on learners' performance or the products they produce, online instructors should have learners write a short reflection where they identify the criteria their work/performance was judged against, assess where their work/performance does not match the targeted goals, and decide what action(s) to take to close the gap(s) between current performance and good performance. In addition to encouraging reflection, providing learners with strategies used by successful students and with exemplars of performance are other practical tips for online instructors to promote the self-regulation aspect of LP in their learners.

We identified the co-regulation aspect of LP as instances where an individual scaffolds and regulates another's learning when the latter might need some help with some aspects of the task, is not doing well in the task, or is not behaving properly in order to carry out the activity. As Hadwin, Järvelä, and Miller's (2011) state, co-regulation is "a manifestation of emergent interaction within the zone of proximal development” (p. 73). In promoting the co-regulation aspect of LP in learners, a crucial question 
for online instructors is: How can I make sure my students work within each other's zone of proximal development in the online learning environment? Here we offer a few general suggestions. One is to assign small group projects rather than individual assignments. Before the project is due, set up a communal area where group members can post misunderstandings or questions that are a source of struggle or uncertainty. Encourage students to seek help from each other in order to figure out how to resolve issues and concerns. Peer sharing of feedback and productive approaches and strategies will allow individual group members to see it is possible to work through roadblocks with the assistance of each other. Of course, just putting learners in groups and encouraging them to help and peer tutor one another does not always lead to success. For this reason, instructors should monitor learners' interactions with each other in the public forums to check the spread of misinformation as well as to assess when to provide assistance and when to step back to let learners work through their difficulties on their own. The second suggestion for making sure the students work within each other's zone of proximal development in the online learning environment is concerned with individual assignments. Even when online learners are working on individual assignments, opportunities for peer tutoring can be created through the use of public forums/discussion spaces. For example, before an assignment is due, instructors can set up these interactional spaces to allow learners the opportunity to post individually prepared assignments to receive input from the class.

Finally, we identified the shared-regulation aspect of LP as instances where individuals work together to regulate each other's learning. Järvelä, Järvenoja, Malmberg, and Hadwin (2013) state that shared regulation takes place when groups regulate themselves by focusing on communal goals, coconstructing plans, and arriving at shared task perceptions through group level monitoring and evaluation of their collective progress. This means that in online learning environments, a joint activity is where instructors will see their students demonstrate the shared regulation aspect of LP. Below are a few practical tips for instructors in promoting this aspect of LP.

At the outset of a group project, group members can be directed through discussion or chat to examine their understanding of the project's instructions by putting into their own words what the project's deliverable should be and to identify the individual tasks or processes that must be addressed, any new skills that are required, as well as areas of confusion that require further clarification. Instructor initiated prompts guiding these discussions may include: As a group, have you reviewed the project instructions? Do you fully understand the requirements? While the group members are executing the project, they can be asked to post progress reports on their collective efforts in the discussion or chat areas. In their progress reports, learners can describe the group's plan, what has been accomplished, what has been working and what has not, and how they might consider changing their approach. Instructor initiated prompts guiding these discussions may include: As a group, have you set aside time to evaluate the quality of your work? How will you measure the success of your project? Once the project is complete, the group members can be directed to participate in a reflection activity via a discussion forum or chat where they can examine how well their planning and monitoring efforts worked, how their efforts were divided among particular types of tasks and activities, and how they might have changed their approach in retrospect. Instructor initiated prompts guiding these discussions may include: What are some take-aways? What have you learned from this group work experience? What will you stop doing, continue doing, or try to do differently, either on an individual or group basis? How will you apply what you learned from this experience for your future group projects?

\section{Significance}

In conclusion, this paper extends and clarifies the current LP construct, a recently proposed addition to the CoI framework, by highlighting the salient differences among self-regulation, coregulation, and socially shared regulation identified by Volet, Vauras, and Salonen (2009), Hadwin, 
Järvelä, and Miller (2011), Hadwin and Oshige (2011), and Grau and Whitebread (2012). The differences identified among self-, co-, and shared regulation have led us to conclude that the LP construct includes the three-phase model of the cyclical processes (planning, monitoring, and reflection) at three levels: an individual looking after his/her own activity (self-regulation); an individual scaffolding and regulating another's learning (co-regulation); and individuals working together to regulate each other's learning (shared regulation). We demonstrated each regulation type within the LP construct with examples found in the discourse of online learners

As the pivotal role of self-regulation has been widely accepted in online learning literature (Artino \& Stephens, 2009; Bol \& Garner, 2011; Cho \& Shen, 2013; Sun \& Rueda, 2012), much interest is focused on identifying pedagogical strategies to help foster regulatory behaviors in online learners, both at the individual and group levels. In this paper, we argue that the LP construct needs to be included in those conversations. We further contend that examining the LP construct through the lens of the three regulatory behaviors, self- co-, and shared regulation, will deepen our understanding of this important construct. And such enhanced understanding will help instructors develop appropriate instructional strategies to foster regulatory behaviors in online learners.

\section{References}

Akyol, Z., \& Garrison, D. R. (2011). Assessing Metacognition in an Online Community of Inquiry. The Internet and Higher Education, 14(3), 183-190. doi: 10.1016/j.iheduc.2011.01.005

Arbaugh, J. B. (2008). Does the community of inquiry framework predict outcomes in online MBA courses? The International Review of Research in Open and Distance Learning, 9(2), 1-21.

Artino, A.R., \& Stephens, J. M. (2009). Beyond grades in online learning: Adaptive profiles of academic self-regulation among naval academy undergraduates. Journal of Advanced Academics, 20(4), 568-601.

Benbunan-Fich, R., \& Hiltz, S. R. (2003). Mediators of the effectiveness of online courses. Professional Communication, 46(4), 298-312.

Bol, L., \& Garner, J. K. (2011). Challenges in supporting self-regulation in distance education environments. Journal of Computing in Higher Education, 23(2-3), 104-123. doi:http://dx.doi.org/10.1007/s12528-011-9046-7

Boston, W., Diaz, S. R., Gibson, A. M., Ice, P., Richardson, J., \& Swan, K. (2009). An exploration of the relationship between indicators of community of inquiry framework and retention in online programs. Journal of Asynchronous Learning Networks, 13(3), 67-83.

Cho, M. -H., \& Shen, D. (2013). Self-regulation in online learning. Distance Education, 34(3), 290-301. doi: 10.1080/01587919.2013.835770

De Wever, B., Schellens, T., Valcke, M., \& Vankeer, H. (2006). Content analysis schemes to analyze transcripts of online asynchronous discussion groups: A review. Computers \& Education, 46(1), 6-28. doi:10.1016/j.compedu.2005.04.005

DiRienzo, C., \& Gregory, L. (2014). Online versus face-to-face: Does delivery method matter for undergraduate business school learning? Business Education \& Accreditation, 6(1), 1-11. 
Garrison, D. R., \& Akyol, Z. (2013). Toward the development of a metacognition construct for communities of inquiry. The Internet and Higher Education, 17, 84-89. doi:10.1016/j.iheduc.2014.10.001

Garrison, D. R., Anderson, T., \& Archer, W. (1999). Critical inquiry in a text-based environment: Computer conferencing in higher education. The Internet and Higher Education, 2, 87-105. doi:10.1016/S1096-7516(00)00016-6

Grau, V., \& Whitebread, D. (2012). Self and social regulation of learning during collaborative activities in the classroom: The interplay of individual and group cognition. Learning and Instruction, 22(6), 1-12. doi:10.1016/j.learninstruc.2012.03.003

Gunawardena, C. N., Lowe, C. A., \& Anderson, T. (1997). Analysis of a global online debate and the development of an interaction analysis model for examining social construction of knowledge in computer conferencing. Journal of Educational Computing Research, 17(4), 397-431.

Hadwin, A. F. (2008). Self-regulated learning. In T. L. Good (Ed.), $21^{\text {st }}$ century education: A reference handbook (pp. 175-183). Thousand Oaks, CA: Sage Publications.

Hadwin, A. F., Järvelä, S., \& Miller, M. (2011). Self-regulated, co-regulated, and socially shared regulation of learning. In B. J. Zimmerman \& D. H. Schunk (Eds.), Handbook of self-regulation of learning and performance (pp. 65-84). Routledge.

Hadwin, A., \& Oshige, M. (2011). Self-regulation, coregulation, and socially shared regulation: exploring perspectives of social in self-regulated learning theory. Teachers College Record, 113(2), 240264.

Hayes, S. (2014). A mixed methods study of shared epistemic agency in team projects in an online baccalaureate nursing course (Doctoral dissertation, University at Albany, State University of New York). Retrieved from Dissertations and Theses database (UMI no. 3667396).

Henri, F. (1992). Computer conferencing and content analysis. In A. R. Kaye (Ed.), Collaborative learning through computer conferencing: The Najaden Papers (New York (pp. 117-136). New York: Springer New York.

Hsieh, H.-F. \& Shannon, S. E., (2005). Three approaches to qualitative content analysis. Qualitative Health Research, 15(9), 1277-1288. doi: 10.1177/1049732305276687

Iiskala, T., Vauras, M., \& Lehtinen, E. (2004). Socially shared metacognition in peer learning? Hellenic Journal of Psychology, 1, 147-178.

Iiskala, T., Vauras, M., Lehtinen, E., \& Salonen, P. (2011). Socially shared metacognition of dyads of pupils in collaborative mathematical problem-solving processes. Learning and Instruction, 21, 379-393.

Järvelä, S., Järvenoja, H., Malmberg, J., \& Hadwin, A. F. (2013). Exploring Socially Shared Regulation in the Context of Collaboration. Journal of Cognitive Education and Psychology, 12(3), 267-286. 
Kang, M., \& Im, T. (2013). Factors of learner-instructor interaction which predict perceived learning outcomes in online learning environment. Journal of Computer Assisted Learning, 29(3), 292301. doi: 10.1111/jcal.12005

Mayordomo, R., \& Onrubia, J. (In press). Work coordination and collaborative knowledge construction in a small group collaborative virtual task. The Internet and Higher Education. doi: 10.1016/j.iheduc.2015.02.003

Neuendorf, K. A. (2002). The content analysis guidebook. Thousand Oaks, CA: Sage Publications.

Nicol, D. J., \& Macfarlane-Dick, D. (2006). Formative assessment and self-regulated learning: a model and seven principles of good feedback practice. Studies in higher education, 31(2), 199-218. Doi: $10.1080 / 03075070600572090$

Rourke, L., Anderson, T., Garrison, D. R., \& Archer, W. (2001). Methodological issues in the content analysis of computer conference transcripts. International Journal of Artificial Intelligence in Education, 12, 8-22.

Salonen, P., Vauras, M., \& Efklides, A. (2005). Social interaction - what can it tell us about metacognition and co-regulation in learning? European Psychologist, 10(3), 199-208. Doi: 10.1027/1016-9040.10.3.199

Shapiro, S. L., \& Schwartz, G. E. (2000). The role of intention in self-regulation: Toward intentional systemic mindfulness. In M. Boekaertz, P. R. Pntrich, and M. Zeidner. (Eds). Handbook of selfregulation (pp. 255-270). Burlington, MA: Elsevier Academic Press.

Shea, P., Hayes, S., Uzuner Smith, S., Vickers, J., Bidjerano, T., Gozza-Cohen, M., Jian, S, Pickett, A., Wilde, J. \& Tseng, C. (2013). Online Learner Self-Regulation: Learning Presence Viewed through Quantitative Content- and Social Network Analysis. International Review of Research in Open and Distance Education, 14(3), 428-461.

Shea, P., Hayes, S., Uzuner-Smith, S., Gozza-Cohen, M., Vickers, J., \& Bidjerano, T. (2014). Reconceptualizing the Community of Inquiry framework: Exploratory analysis. The Internet and Higher Education, 23, 9-17. doi:10.1016/j.iheduc.2014.05.002

Shea, P., Hayes, S., Smith, S. U., Vickers, J., Bidjerano, T., Pickett, A., Gozza-Cohen, M., Wilde, J. \& Jian, S. (2012). Learning presence: Additional research on a new conceptual element within the community of inquiry (CoI) framework. The Internet and Higher Education, 15(2), 89-95. doi:10.1016/j.iheduc.2011.08.002

Stodel, E. J., Thompson, T. L., \& MacDonald, C. J. (2006). Learners' perspectives on what is missing from online learning: Interpretations through the community of inquiry framework. The International Review of Research in Open and Distance Learning, 7(3), 1-16.

Sun, J. C. -Y., \& Rueda, R. (2012). Situational interest, computer self-efficacy and self-regulation: Their impact on student engagement in distance education. British Journal of Educational Technology, 43(2), 191-204. 10.1111/j.1467-8535.2010.01157.x

Swan, K., \& Ice, P. (2010). The community of inquiry framework ten years later: Introduction to the special issue. The Internet and Higher Education, 13, 1-4. doi:10.1016/j.iheduc.2009.11.003 
Traver, A. E., Volchok, E., Bidjerano, T., \& Shea. (2014). Correlating community college students' perceptions of community of inquiry presences with their completion of blended courses. The Internet and Higher Education, 20, 1-9. doi:10.1016/j.iheduc.2013.09.001

Vauras, M., Iiskala, T., Kajamies, A., Kinnunen, R., \& Lehtinen, E. (2003). Shared-regulation and motivation of collaborating peers: A case analysis. Psychologia, 46(1), 19-37. http://dx.doi.org/10.2117/psysoc.2003.19

Volet, S., Summers, M., Thurman, T. (2009). High-level co-regulation in collaborative learning: How does it emerge and how is it sustained? Learning and Instruction, 19(2), 128-143. doi:10.1016/j.learninstruc.2008.03.001

Volet, S., Vauras, M., \& Salonen, P. (2009). Self- and social regulation in learning contexts: An integrative perspective. Educational Psychologist, 44(4), 215-226. doi: $10.1080 / 00461520903213584$

Wertz, R. E. (2014). Toward a new model within the community of inquiry framework: Multivariate linear regression analyses based on graduate student perceptions of learning online. (Doctoral dissertation, Purdue University) Retrieved from Dissertations and Theses database (UMI No. 3636686)

Zimmerman, B. J. (1989). A social cognitive view of self-regulated academic learning. Journal of Educational Psychology, 81(3), 329-339. doi: 10.1037/0022-0663.81.3.329

Zimmerman, B. J. (1990). Self-regulating academic learning and achievement: The emergence of a social cognitive perspective. Educational Psychology Review, 2(2), 173-201.

Zimmerman, B. J. (2008). Investigating self-regulation and motivation: Historical background, methodological developments, and future prospects. American Educational Research Journal, 45(1), 166-183. doi: 10.3102/0002831207312909 
Appendix Refined Coding Scheme for LP

\begin{tabular}{lllll}
\hline Category & Code & Indicator & Description & Example \\
\hline $\begin{array}{l}\text { Forethought } \\
\text { \& Planning }\end{array}$ & FP1 & Goal Setting & $\begin{array}{l}\text { Deciding upon specific } \\
\text { actions and outcomes }\end{array}$ & $\begin{array}{l}\text { At the end of next week, as a team, } \\
\text { we have to submit a summary of } \\
\text { our discussion points. Our goal is } \\
\text { to submit a two-page position } \\
\text { paper defending the position } \\
\text { against outsourcing }\end{array}$ \\
& & & and
\end{tabular}

\begin{tabular}{|c|c|c|c|c|}
\hline & FP2 & Planning & $\begin{array}{l}\text { Deciding on } \\
\text { methods/strategies } \\
\text { appropriate for the task }\end{array}$ & $\begin{array}{l}\text { I was thinking we should decide } \\
\text { what arguments we want to use in } \\
\text { this paper }\end{array}$ \\
\hline & FP3 & $\begin{array}{l}\text { Coordinating, } \\
\text { delegating or } \\
\text { assigning tasks to } \\
\text { self and others }\end{array}$ & $\begin{array}{l}\text { Distributing, sequencing } \\
\text { tasks and sub-tasks to } \\
\text { others/self for future } \\
\text { completion }\end{array}$ & $\begin{array}{l}\text { I will take care of the intro and the } \\
\text { summary. I have to work all night } \\
\text { tonight. I will submit it for the } \\
\text { group tomorrow evening sometime }\end{array}$ \\
\hline \multirow[t]{7}{*}{ Monitoring } & MO1 & $\begin{array}{l}\text { Checking } \\
\text { confirming }\end{array}$ & $\begin{array}{l}\text { Confirming that a task or } \\
\text { process aligns with } \\
\text { instructions }\end{array}$ & $\begin{array}{l}\text { I have come to the same } \\
\text { conclusion that we first have to do } \\
\text { an interview with another } \\
\text { profession. }\end{array}$ \\
\hline & MO2 & $\begin{array}{l}\text { Identifying } \\
\text { problems or issues }\end{array}$ & $\begin{array}{l}\text { Identifying difficulties } \\
\text { related to materials, } \\
\text { technologies, process that } \\
\text { interfere with progress }\end{array}$ & $\begin{array}{l}\text { I believe the assignment is } 500 \\
\text { words or less so we may need to } \\
\text { skimp down a bit. }\end{array}$ \\
\hline & MO3 & $\begin{array}{l}\text { Noting } \\
\text { completion of } \\
\text { tasks or progress }\end{array}$ & $\begin{array}{l}\text { Comments about } \\
\text { tasks/activities completed } \\
\text { to support attaining a goal }\end{array}$ & $\begin{array}{l}\text { I did some research and then typed } \\
\text { up the employer section. }\end{array}$ \\
\hline & MO4 & Evaluating quality & $\begin{array}{l}\text { Evaluating the quality of } \\
\text { a process or product, its } \\
\text { content or its constituent } \\
\text { parts }\end{array}$ & $\begin{array}{l}\text { This information needs to be } \\
\text { formatted better, for easier reading } \\
\text { for the patient. }\end{array}$ \\
\hline & MO5 & $\begin{array}{l}\text { Appraising } \\
\text { personal interest, } \\
\text { engagement or } \\
\text { reaction }\end{array}$ & $\begin{array}{l}\text { Comments about self or } \\
\text { others' engagement, } \\
\text { interest, commitment or } \\
\text { participation. Also } \\
\text { includes } \\
\text { reactions to tasks, } \\
\text { materials and activities }\end{array}$ & $\begin{array}{l}\text { I found that information [in the } \\
\text { chapter] all new and a little scary. }\end{array}$ \\
\hline & MO6 & $\begin{array}{l}\text { Recognizing } \\
\text { learning behaviors } \\
\text { of self or group }\end{array}$ & $\begin{array}{l}\text { Statements about } \\
\text { individual or group } \\
\text { preferences, strengths or } \\
\text { weaknesses as learners }\end{array}$ & $\begin{array}{l}\text { I am one who likes to explore new } \\
\text { programs and put together an } \\
\text { object without reading directions }\end{array}$ \\
\hline & MO7 & $\begin{array}{l}\text { Advocating effort } \\
\text { or focus }\end{array}$ & $\begin{array}{l}\text { Encouraging others to } \\
\text { contribute or focus on } \\
\text { tasks, materials and }\end{array}$ & $\begin{array}{l}\text { Please let me know if there are any } \\
\text { other ideas }\end{array}$ \\
\hline
\end{tabular}




\begin{tabular}{|c|c|c|c|c|}
\hline & & & activities. & \\
\hline & MO8 & $\begin{array}{l}\text { Noting use of } \\
\text { strategies }\end{array}$ & $\begin{array}{l}\text { Statements illustrating } \\
\text { that students are mindful } \\
\text { and aware of the } \\
\text { strategies that they are } \\
\text { using }\end{array}$ & $\begin{array}{l}\text { I decided to extract concepts from } \\
\text { the graphic organizer on page } 26 \\
\text { and Google each word to try and } \\
\text { make sense how the concepts tie } \\
\text { together }\end{array}$ \\
\hline \multirow[t]{4}{*}{ Strategy Use } & SU1 & $\begin{array}{l}\text { Seeking, offering } \\
\text { or providing } \\
\text { guidance }\end{array}$ & $\begin{array}{l}\text { Requesting, offering, or } \\
\text { providing guidance or } \\
\text { describing efforts to } \\
\text { obtain guidance or help } \\
\text { related to learning } \\
\text { materials, tasks, processes } \\
\text { or products }\end{array}$ & $\begin{array}{l}\text { If you need any assistance, please } \\
\text { let me know what I can do to help } \\
\text { you out }\end{array}$ \\
\hline & SU2 & Reviewing & $\begin{array}{l}\text { Comments noting the } \\
\text { need to review or the } \\
\text { completion of re- } \\
\text { examining content related } \\
\text { to the course }\end{array}$ & $\begin{array}{l}\text { I would need to refer to this } \\
\text { chapter in order to review the } \\
\text { principles of this philosophy }\end{array}$ \\
\hline & SU3 & $\begin{array}{l}\text { Noting outcome } \\
\text { expectations }\end{array}$ & $\begin{array}{l}\text { Statements in which } \\
\text { students acknowledge the } \\
\text { relevance of current tasks } \\
\text { or processes to a future } \\
\text { learning outcome }\end{array}$ & $\begin{array}{l}\text { I think interviewing the dietician } \\
\text { will help us deal with his obesity as } \\
\text { well as ways to address his mother } \\
\text { who thinks he is just "a healthy } \\
\text { growing boy" }\end{array}$ \\
\hline & SU4 & $\begin{array}{l}\text { Making adjustment } \\
\text { in strategy }\end{array}$ & $\begin{array}{l}\text { Recognizing that current } \\
\text { strategy is not working } \\
\text { and trying new strategy }\end{array}$ & $\begin{array}{l}\text { I say we paste the whole thing into } \\
\text { a word document when we're } \\
\text { finished and then paste it back to } \\
\text { the wiki after correcting the font }\end{array}$ \\
\hline \multirow[t]{2}{*}{ Reflection } & RE1 & Change in thinking & $\begin{array}{l}\text { Statements indicating a } \\
\text { change in thinking as a } \\
\text { result of process, product } \\
\text { or outcome }\end{array}$ & $\begin{array}{l}\text { This issue is not as simplistic as I } \\
\text { once thought... }\end{array}$ \\
\hline & RE2 & $\begin{array}{l}\text { Causal attribution } \\
\text { of results }\end{array}$ & $\begin{array}{l}\text { Statements in which } \\
\text { students credit their } \\
\text { results to personal or } \\
\text { group performance }\end{array}$ & $\begin{array}{l}\text { Any minor technology issues and } \\
\text { questions/confusion about the } \\
\text { project were easily solved in } \\
\text { discussions }\end{array}$ \\
\hline
\end{tabular}

